$1-1-1934$

\title{
Black Pox and Other Apple-Bark Diseases Commonly Known as Measles
}

Anthony Berg

Follow this and additional works at: https://researchrepository.wvu.edu/ wv_agricultural_and_forestry_experiment_station_bulletins

\section{Digital Commons Citation}

Berg, Anthony, "Black Pox and Other Apple-Bark Diseases Commonly Known as Measles" (1934). West Virginia Agricultural and Forestry Experiment Station Bulletins. 260.

https://researchrepository.wvu.edu/wv_agricultural_and_forestry_experiment_station_bulletins/261 @ WVU. It has been accepted for inclusion in West Virginia Agricultural and Forestry Experiment Station Bulletins by an authorized administrator of The Research Repository @ WVU. For more information, please contact ian.harmon@mail.wvu.edu. 


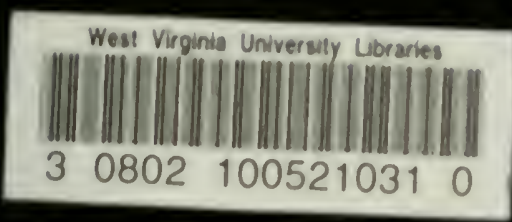


Digitized by the Internet Archive in 2010 with funding from

Lyrasis Members and Sloan Foundation 


\title{
Black Pox and Other Apple-Bark
}

\section{Diseases Commonly Known} as Measles

bY ANTHONY BERG

\author{
AGRICULTURAL EXPERIMENT STATION \\ COLLEGE OF AGRICULTURE, WEST VIRGINIA UNIVERSITY \\ F. D. FROMME, Director \\ MORGANTOWN
}




\section{AGRICULTURAL EXPERIMENT STATION STAFF}

JOHN R. TURNER, Ph.D., LL.D., President of the University

F. D. FROMME, Ph.D., Dean and Director

\section{AGRONOMY AND GENETICS}

R. J. Gorber, Ph.D.

Agronomist and Geneticist.

W. H. Pierre, Ph.D.

Associate Agronomist.

T. C. Mellvaine, Ph.D. Assistant Agronomist.

G. G. Pohlman, Ph.D. Assistant Agronomist.

C. R. Burnham, Ph.D Assistant Geneticist.

H. K. Rowley, M.S. Agr.**; Seed Analyst.

ANIMAL HUSBANDRY

E. A. Livesay, D.Sc. Animal Husbandman.

C. V. Wilson, M.S. Assistant Animal Husbandman.

J. H. Longwell, M.A. Assistant Animal Husbandman.

R. H. Tuckwiller, B.S. Agr.* Assistant Animal Husbondman.

J. H. Rietz, D.V.M.;:; Associate Veterinarian.

E. N. Moore, D.V.M.*; Assistant Veterinarian.

\section{CHEMISTRY}

R. B. Dustman. Ph.D. Agricultural Chemist.

Chas. E. Weakley, Jr., M.A. Assistant Chemist.

T. B. Leith, M.S.**; Assistant Chemist.

I. J. Duncan, M.S. Assistant in Agricultural Chemistry

A. H. Van Landingham. Ph.D. Assistant in Agricultural Chemistry.

\section{DAIRY HUSBANDRY}

H. O. Henderson, Ph.D. Dairy Husbandman.

L. M. Thurston, Ph.D. Associate Dairy Husbandman.

G. A. Bowling, M.S. Assistant Dairy Husbandman.

R. A. Ackerman, M.S. Agr.‡ Assistant Dairy Husbandman.

\section{ENTOMOLOGY}

L. M. Peairs, Ph.D. Entomologist.

W. E. Rumsey, B.S. *:*; State Entomologist.

Edwin Gould, B.S. Agr. Assistant in Entomology.

\section{FARM MANAGEMENT}

W. W. Armentrout, Ph.D. Associate Farm Economist.

F. D. Cornell, Jr., M.S. Assistant Farm Mechanician.

R. O. Stelzer, M.S. Assistant in Farm Economics.

\section{HOME ECONOMICS}

Rachel H. Colwell, M.A. Home Economist.

Hazel C. Cameron, M.A. Research Specialist in Nutrition.

\section{HORTICULTURE}

H. E. Knowlton, Ph.D. Horticulturist.

K. C. Westover, M.S. Assistant Horticulturist.

Leif Verner, M.S. Assistant Horticulturist.

E. N. McCubbin, M.A. Assistant in Horticulture.

A. P. Dye, M.S. Assistant in Horticulture.

W. H. Childs, M.S. Assistant in Horticulture.

\section{PLANT PATHOLOGY}

C. R. Orton, Ph.D. Plant Pathologist.

Anthony Berg, M.S. Associate Plant Pathologist.

L. H. Leonian, Ph.D. Associate Plant Pathologist.

F. J. Schneiderhan,Ph.D+t Associate Plant Pathologist.

\section{POULTRY HUSBANDRY}

\section{T. B. Clark, M.S}

Assistant in Poultry Research.

E. T. Wightman, M.S.

Assistant in Poultry Research.

* In cooperation with the U. S. Department of Agriculture, Washington, D. C. + In charge of the Lakin Experiment Farm, Lakin, W. Va.

* $*$ In cooperation with the State Department of Agriculture, Charleston, W. Va. \# In charge of the Reymann Memorial Farms, Wardensville, W. Va. it In charge of the University. Experiment Farm, Kearneysville, W. Va. 


\title{
Black Pox and Other Apple-Bark Diseases Commonly Known as Measles
}

\author{
by ANTHONY BERG
}

$I^{\prime}$

N 1912 Hewitt and Truax reported an obscure apple-bark disease from Arkansas and gave it the name "measles" hecause it manifested itself in the form of papular elevations on the smooth bark, which in certain varieties had a reddish or purplish tinge suggestive of human measles. Since that time diseases of similar appearance have been reported from varions parts of the country and inlentified as "measles".

Although various theories have been advanced in explanation of the cause of "apple measles", there has never" been presented sufficient experimental evidence to substantiate them. It has, therefore, been an open question in the minds of some plant pathologists whether the various forms of bark diseases which have been included under the term "measles" are simply varietal responses to the same causative agent or whether they represent separate and distinct diseases.

In the spring of 1915 a disease of this type came to the attention of the writer while inspecting a large commercial orchard in the Kanawha Valley near Charleston, West Virginia. The disease at that time was confined to a few Astrachan trees situated near the middle of the orchard. On subsequent visits to this orchard it was noted that the disease was gradually spreading to other varieties, and by 1929 the orchard was abandoned because the disease had practically destroyed some 16,000 trees. By this time this disease was known to exist in numerous other orchards throughout the state, but nowhere else was it causing such destruction. It was evident, however, that if given the proper conditions it was capable of becoming a serions menace to $0 m$ apple orchards.

Since very little was known about the nature and cause of "apple measles", the West Virginia Agricultural Experiment Station undertook an intensive study of this trouble in 1929. The investigations so far have disclosed that the various types of papular and rough-bark diseases commonly included mder the term measles are not all manifestations of the same causative agent, but represent distinct diseases. It has also been shown that at least one type is caused by a parasitic

\section{ACKNOWLEDGMENT}

The writer gratefully acknowledges the assistance reudered by the following persons in furnishing diseased material from their respective localities: H. W. Anderson. University of Illinois: R. F. Crawford. New Mexico State College: T. D. Pearson, State College, Mississipni: E. il. Hildebrand. Cornell Tniversity; Paul H. Shepard, Direetor. Missouri State Fruit Experiment Station: J. C. Dunegan. Faretteville. Ark.: Donald Cation, East Lansing. Michigan: Wm. H. Martin. New Brunswick. N. J.; and Robt. C. Simpson, Vincennes. Ind. For the Latin description of the organism H. papulosum the writer is indebted to C. G. Brouzas. 
fungus. This disease will hereafter be designated as "black pox" ; the disease on Delicious as "internal-bark necrosis"; and the original disease of Hewitt and Truax as "measles". A short artice ( 7 ) and two abstracts (8), (9) have already been published from this laboratory, but it now seems advisable to sum up the results of the writer's investigations to date in more detailed manner.

\section{HISTORICAL}

\begin{tabular}{|c|c|}
\hline $\begin{array}{l}\text { ark regions } \\
\text { st by Hewi } \\
\text { ple diseas } \\
\text { ice. The } \\
\text { rk in the } \\
\text { ight red ne } \\
\text { mmit. As } \\
\text { til the limb }\end{array}$ & $\begin{array}{r}\text {.11 Arkansas. The dise } \\
\text { (11) in Arkansas in } 1913 \\
\text { "measles", a name which it } \\
\text { scribed as first appearing on } \\
\text { scattered red pycnidia-like p } \\
\text { scumference and dark red to } 1 \\
\text { presses the pustules becon } \\
\text { ien, making the bark }\end{array}$ \\
\hline
\end{tabular}

The origin. vbservers were mable to associate the disease with any parasitic organism. They concluded that it was due to some physiological derangement and suggested tne possibility that the lenticels when forming are diverted from their normal development in such fashion that layer after layer of cork is formed instead of the ordinary spongy tissue with nly occasional corky layers. They cited in support of this theor. the fact that the number of lenticels diminishes as the number of pustules incre... ss. They found but few cases in which the death of a tree could be traced with reasonable certainty to this disease. However, in nearly all cases the vitality of the tree was noticeably impaired, ar ' in many cases limbs died apparently as a result of the trouble.

Rose (1i) in 1914 reported under the name of "pimple canker" a disease which he considered to be the same as the "measles" disease described by Hewitt and Truax, and stated that it had been known to exist in Missonri since 1904. In another paper published in 1917 Rose (18) described a rough bark or scurfy bark canker of apples which he believed to show similarity to the disease described by Hewitt, but which, from his description and illustrations, appears to be of a different nature. He isolated several forms of bacteria from diseased bark and presented evidence that the disease might be cansed by one of these (Pseudomonas papulans).

In 1916 Adams (1) reported the occurrence of a measles disease in Pennsylvania on the variety Smith's Cider which he could not associate with a parasitic organism. The most conspicuous symptoms of this disease were the minute reddish or dark-brown elerations which were found on all sides of the twig and which stood out most prominently on the smooth bark. A more advanced rough-bark stage was also observed. Adams concurred in the opinion of Hewitt that the trouble was physiological and perhaps an abnormal development of the lenticels. 
In 1919 "measles" was reported as being very common and destructive in s.ew Mexico (2). The disease was believed to be due to excessive amounts of nitrates in the soil. Sulsequent reports of the disease from New Mexico indicate that .Jonathan (3) is the variety most severely attacked by measles, althoug! practically all varieties grown in the state are susceptible. The 'isease (1) is reported as rarely appearing on wood under four vocis's " age, althongh in 1927 (5) it was found on one-yer.i wood. Unth trees are reported as being more susceptible than shealthy, vi of soil (6) from around measled itrees s salts. This soil was placed in pots, and $h$. Measles developed on these trees while check ng trees. Analysis rent of soluble were planted. ir healthy.

In 1924 (15) Rhoads published the resuli. tions on apple measles at the Missouri Fruit Ex special reference to the comparative susceptibili. observaation with resistance of apple varieties to the disease. His work constitt: bensive publication on the subject to date. He most compreliterature on apple measles for the first time is compiled and a ussed. Descriptions are given of both the racroscopic and microscopic characters of the disease under observation. Rhoads classified the disease into three more or less distinct types. These are an isolated pustular type, an aggregate pustular or scurfy type, and a canker type.

Rhoads states, "In Missouri the writer hc found no relation between drainage of the soil, the appliration of $f_{t}$ ilizers, tillage and cover erops, or the method of prunir : and the prevalence of apple measles .... While this disease clearly is a reaction of the bark to internal disturbances of the equilibrium, the causal agent is still in doubt. The trouble does not appear to be eaused by a organism, either fungus or bacterial." He further states, "Only in ery few cases observed by the writer has a sickly condition of the tree or the dying of the branches been attributed to measles."

Hopkins (12), 1927, reports and deseribes an apple bark-blistering disease from South Africa which spread with alarming rapidity. This disease was first brought to his attention in 1924. It is believed to resemble the bark disease which Dean Rose (18) ascribed to Ps. papulans. The disease is described as almost invariably making its first appearance at the base of the tree and then working upward. The young lesions have the appearance of blisters and vary in diameter from a fraction of a centimeter to a centimeter or more. The outline is often very irregular. The larger blisters are formed by the coalescing of the smaller ones. The skin of the blisters is formed by the epidermis of the bark and when pressed by the fingers it slips away, revealing a soft, mushy layer composed of giant cells still greenish in color. In a few days small longitudinal cracks appear in the center of the blister and the outer skin begins to loosen and peel away. The soft layer of giant cells becomes spongy and gradually oxidises to a light brown, then to dark brown and finally can be rubbed away as a darkbrown powder. A bacterial organism was isolated from the diseased 
tissue. Inoculation with this organism in the greenhouse and in the field reproduced the disease in miniature when the bark was needlepricked before inoculation, but no results were obtained when the inoculations were made on mninjured bark. The suggestion is made that sunscald may be a predisposing factor.

Lacy and Dowson (1.3), 1931, describe a bark disease on seedling. apple trees characterized by horseshoe or circular cracks in the bark: Scattered among these were small raised swellings or blisters $1 / 8$ of an inch in diameter.

Numerous isolations from these lesions yielded practically pure cultures of bacterial colonies, the cultural characters of which appeared to be very similar to $B$. amylovorus. Numerous prick inoculations were made on apple stems, and positive inoculations were obtained in most cases, from which the organism was easily reisolated. The organism, although bearing certain likeness to $B$. amylovorus, is regarded as identical to $P s$. papulans Rose. The suggestion is made that the latter organism should be considered as a weak parasite, producing disease only when some physiological condition renders the trees liable to attack.

Roberts (16) in 1934 reports the isolation of a bacterium similar to Ps. papulans Rose from early lesions of a disease which he had previously described as apple target canker. Inoculation with this organism on Delicious produced lesions typical of the early stage of the disease. These results, howerer, are not conclusive, since similar lesions also appeared on the noninoculated checks. Roberts is of the opinion that "apple measles", target canker, and the rough-bark disease may prove to be identical since their early stages are alike and what appears to be the same species of bacterium has been isolated from the early stages of them all.

Since none of these workers has definitely established the cause of the disease described as measles, it is impossible to determine whether the various diseases reported by them as measles are identical with the originally described disease. Although Hewitt's illustrations and descriptions are adequate, the confusion has arisen from the fact that the disease presents several stages in its development. Furthermore, since our investigations have established that there are several distinct and widely distributed papular diseases that have been called "measles", it is not unlikely that specifically distinct diseases have been confused with stages of the originally described disease. Since Hewitt's original material is no longer available, the writer has had to make comparisons from illustrations and descriptions rather than from preserved specimens. It is apparent, however, that the disease described by Hewitt as "measles", by Rose (1 7 ) as "pimple canker", and by Adams (1) as "measles" is probably the same disease as the disease described from New Mexico and later from Missouri by Rhoads. Rhoads (15) also described a type of disease on .Jonathan,

* Phytopath. 14 : 295; also pl. xx, fig. C. 


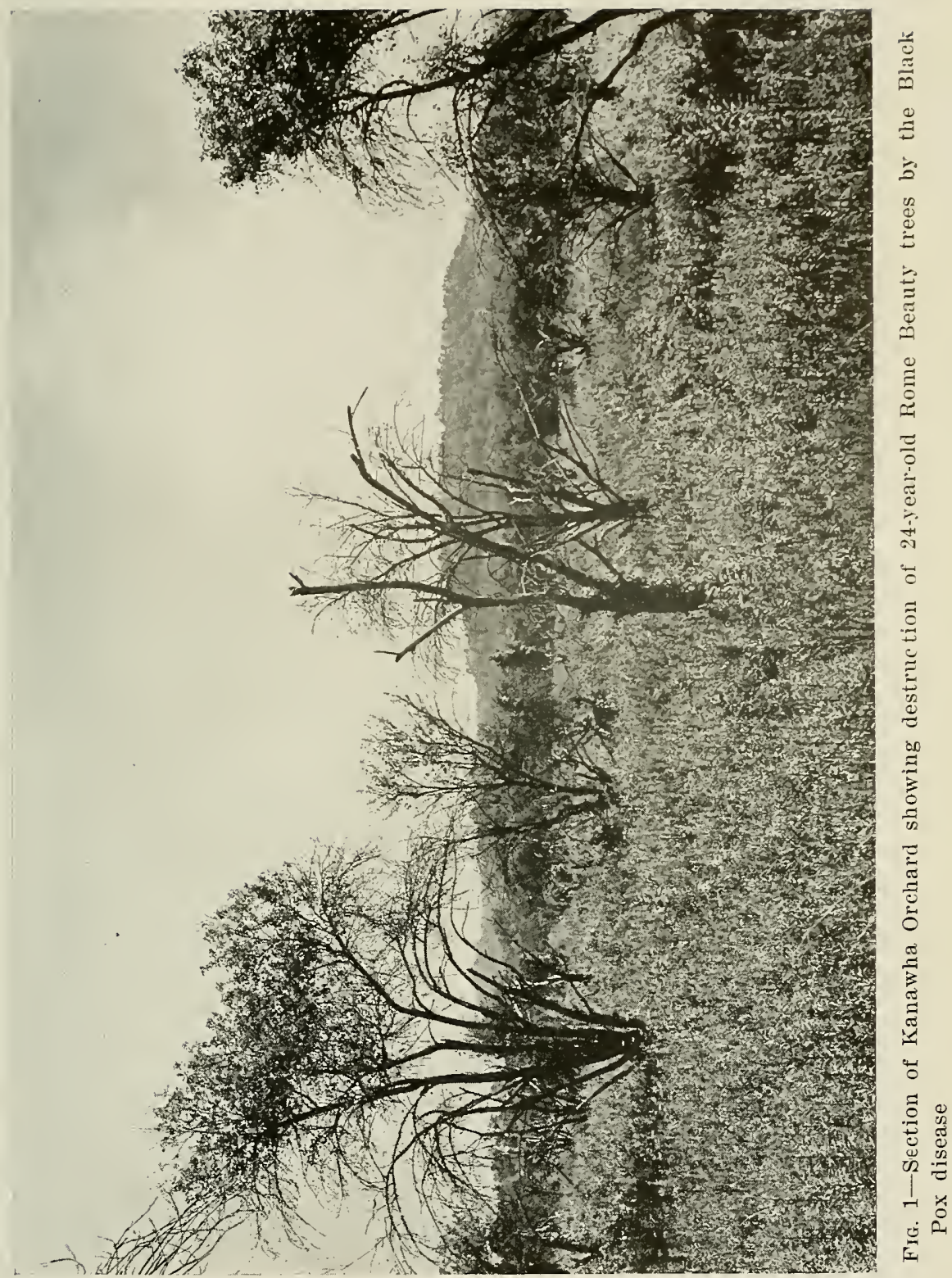


in which the dead tissues become encysted in the bark and the external surface lumpy in appearance. This corresponds elosely to the bark necrosis type described later on Delicious. The diseases ascribed to Ps. papulans by Hopkins (12), by Lacy and Dowson (13), and by Roberts (16) certainly do not correspond to Hewitt and Truax's description and illustration of "apple measles".

\section{EXPERIMENTAL}

The ever-increasing spread and severity of apple measles in West Virginia, especially in the Kanawha orchard, indicated the need and offered the opportunity for a systematic study. Accordingly a project was organized the purpose of which was to attempt to determine the cause of the disease; to verify or disprove the various theories which had been advanced in explanation of its nature; to study the relative susceptibility of different apple varieties; to determine whether the different types of measles are varietal responses or whether they represented different diseases; and to devise means of control, if possible.

Experiments at the Kanawha Orchard in 1929. In the hope that the mode of dissemination might furnish a clue as to the nature and cause of the trouble, the first experiments were started to determine this. For this purpose 24 young Delicious trees and an equal number of:young Astrachan trees were planted under the overhanging branches of 18-year-old Astrachan trees that were badly diseased. In previous surveys of West Virginia orchards it had been found that Delicious and Astrachan were the varieties most commonly affected with "measles". However, the type of disease on Astrachan was quite different in appearance from that on the Delicious. Since there were no Delicious trees in the Kanawha orehard, an opportunity was afforderl to expose both varieties to the Astrachan type of "measles" only, and to determine whether we were dealing with two distinet diseases or whether the difference in appearance was simply a varietal response.

In another experiment 50 young Astrachan trees were planted beneath the branches of infected Astrachan trees. A section of the trunk of each of the small trees, 8 to 10 inches in length, was covered with a cylinder of celluloid closed at the ends by means of a muslin sleeve cemented to the celluloid (Fig. 2). Before affixing the cylinders the portion to be enclosed was thoroughly washed with a strong solution of nicotine sulphate to kill or drive away any insects that might be present $_{2}$ As further protection against entrance of insects, tree tanglefoot was applied to the tree at the point where the muslin was gathered and tied. Above each cylinder a waterproof cone was attached. This arrangement excluded water and insects but admitted air and light. If the disease were non-parasitic, due to unfavorable soil conditions, or of a systemic virus nature, it was logical to suppose that it would make its appearance on the areas protected by the cylinder as well as on the exposed parts of the tree. On the other hand, should the disease be caused by an external agent, depending upon water or insects for 


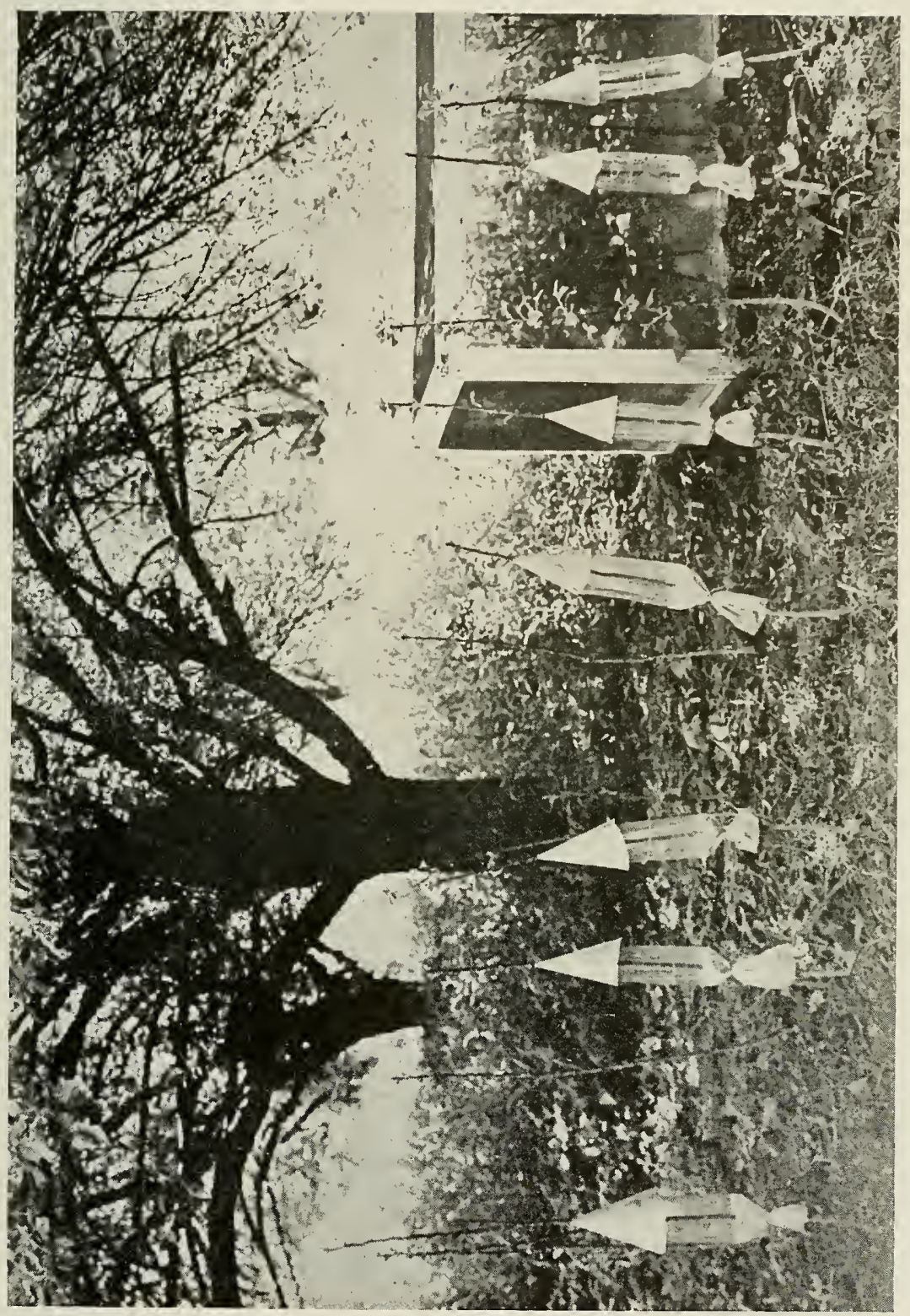

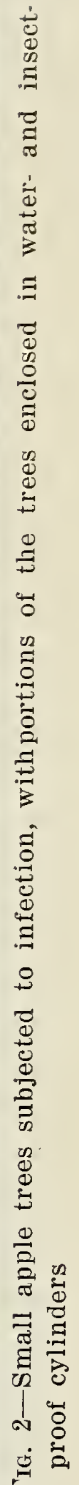


its transmission, the enclosed areas might well be expected to remain free of the disease.

In a third experiment small trees were planted under eages of 14-, 20-, and 30-mesh copper wire respectively. 'The cages were so placed that the water from the overhanging branches of infected Astrachan trees would drip through the wire tops of the cages and come in contact with the enclosed trees. In this manner air, light, and water were admitted, but insects excluded, at least in the finer-mesh cages. In other caging experiments, trees were enclosed in cheesecloth cages into which various tree-inhabiting hoppers collected from diseased trees were admitted.

To check on the date and duration of the natural infection period in the orchard, portions of water sprouts of the season's growth were enclosed in small celluloid cylinders in a manner similar to that previously described, which was employed in enclosing portions of the trunks of small trees. To insure an abundance of watersprouts some of the lower limbs on the experimental trees had been sawed off in the late summer of the previous season. Watersprouts in lots of ten were. covered at intervals of from seven to ten days from May 15 to the middle of August.

Experiments to control the disease by means of spraying were also initiated. For this purpose eighteen diseased Astrachan trees were selected and divided into three plats. In the dormant spray, Plat 1 was sprayed with copper sulphate 1 to 50 , Plat 2 with miscible oil, and Plat 3 with lime sulphur 1 to 8 . In the summer sprays, three trees in each plat were sprayed with Bordeaux 4-4-50 and the remaining three received lime sulphur, summer strength. 'The spraying commenced at the time of the petal fall with subsequent applications at intervals of ten days until the end of Angust. The usual unsprayed checks were placed at each end and in the middle.

Results of Experiments in 1929. On October 3 a check was made of the season's work and the following results noted: The young Astrachan and Delicious trees planted beneath the overhanging branches of severely-measled Astrachan trees all had become infected. This infection was not confined to growth of the current season but was found also on bark at least three year's old. The Delicious trees were infected with a type of disease which seemed to be the same as that on Astrachan. This type of disease had never been reported on Delicious growing under natural conditions, it being quite distinct from the disease which occurs widely on this variety and which will be described later in this bulletin.

The 50 young Astrachan trees similarly exposed to infection but with part of the trunks enclosed in a celluloid cylinder showed infection on all parts except those protected by the cylinders. This clearly indieated that this type of disease is not a systemic disease but is probably caused by insects or by a micro-0rganism which is carried in the drip water from the overhanging branches. The latter assumption was strengthened by the fact that the trees planted nearest the trunk and 
moler the most densely matted branches became more heavily infected than those planter at the onter limits of the limb spread.

The trees planted in the 20 - and 30 -mesh copper-screen cacres remained free from infection. A few of the trees planted in the 14-mesh cages showed an occasional infecton. Since the trees planted in the cages were also subjected to the drip water from the overhanging diseased branches, one might be led to believe that the disease was caused by insects which could not enter the 20- and 30-mesh screens. However, the fact that leaf spot was very prevalent on the foliage of the overhanging branches and also on the leaves of the small trees planted outside the cages, while the foliage of the trees enclosed in the cages was free from it, indicated that apparently something was faulty with the experiment. The rainfall during the spring and summer months was very lieary, and a considerable amount of verdigris acenmulated on the copper screen, which probably acted as a fungicirle.

In the caging experiments for insect transmission of the disease negative results were obtained. The records taken on the experiment to eheck the time and duration of infection in the orehard showed that no infection had taken plaee before the first week in June and that the heaviest infection occurred from. July 10 to August 8 . In previous observations it had been noted that the new infections usually appear most numerous after mid-summer.

In eompiling the data on the spray experiments, ten watersprouts of the season's growth were taken from each tree. Care was taken to seleet sprouts of equal exposure. The mumber of new infeetions were then counted upon the lower ten inehes of each sprout and tabulated as infections per linear ineh. No outstanding results eould be attributed to any particular treatment. There was, however, a reduetion of approximately 38 pereent in the number of infections on the sprayed plots over the eheeks. These results indieate that this disease can be cheeked to a considerable extent by proper spraying with lime sulphur or Bordeanx in spite of the faet that the equipment which could be obtained for this experiment did not furnish suffieient pressure for the best results. It may also be stated that this disease has always been found to be most severe in orehards where spraying was not properly condueted.

Repeated attempts were made to isolate a eausative organism. Althongh numerous types of fungi and baeteria were isolated from the diseased bark, none of them eould be made to produee the disease upon artifieial inoeulation.

Experiments in 1930. The experiments in 1930 were planned along lines similar to those of the previous year with the objeet of verifying the results already obtained and to obtain sueh additional information as might be possible. Renewed afforts were made to isolate a miero-organism and for that purpose the writer was stationed in the orehard during the growing seasons in order to have the disease under elose and eonstant observation.

Slight modifications were made in some of the experiments. In the experiment to eheek the date and the duration of the period of infeetion, 
the enclosing of water sprouts by means of celluloid cylinders was omitted. In its place young Astrachan trees previously potted and in active growing condition were exposed each week, in lots of ten'trees, beneath the overhanging branches of diseased Astrachan trees. These trees were removed at the end of each week, transported to a branch experiment station at Lakin, West Virginia, about 35 miles from the orchard, and planted in open ground; a new set was then exposed. By this means it was hoped to secure a more accurate check, not only on the time of infection but also on the severity of the infection during each period. This could then be correlated with the weather conditions prevailing during each period.

The caging experiments were conducted on a more extensive scale than during the previous year. A careful watch was kept on the development of various types of leaf and tree-inhabiting hoppers. These insects were collected in the early morning by sweeping the infected trees with a net and were placed upon potted Astrachan trees under cheesecloth cages, which were kept some distance from the orchard.

The spraying experiments to control the disease continued with special emphasis on thoroughly drenching the trunks and limbs during each application.

Although the experimental work in the Kanawha Orchard in 1929 indicated that the Astrachan type of measles was not a physiological disease, it also disclosed the fact that the disease commonly occurring on the Delicions variety was of a different type, and so the possibility of its being physiological still had to be reckoned with. Accordingly an experiment to determine this was conducted in another orchard where the disease occurred on Delicious only. Two badly-measled 14-year-old Delicious trees were selected. The limbs and branches were cut back to short stubs. The rough bark was scraped off and the trees thoroughly sprayed with miscible oil, then washed with a strong nicotine sulphate solution. The trees were then enclosed by a cage which admitted air and light, but exchuded water and insects. Obviously these precautions would preclude any infectious disease on the new growth. However, if the disease was due to internal metabolic derangement or caused by a systemic virus, it would be likely to be perpetuated on the new growth.

Results of Experiments in 1930. Because of the total lack of rainfall during the spring and summer months, no results were obtained on the spraying experiments or on the experiments to check the time and the extent of the period of infection. The insect-caging experiment also gave negative results. The Delicous trees enclosed in the water- and insect-proof house died from lack of moisture.

Isolation of the Causative Organism. There was practically no precipitation from the middle of April to the middle of August, but an appreciable shower at this time sufficed to produce on Astrachan trees a small number of infections which were detected by means of a hand lens just as the epidermis was showing a slight brown discoloration and before any noticeable elevation of the epidermis had taken place. The 
twigs bearing these infections wore immersed for 10 ininutes in $1: 1000$ bichloride of mereury, rinsed in sterile ristiller water, and the spots removed with a sterile scalpel and introducerl into test tubes containing dextrose broth. Ont of a total of 44 spots located. 36 produced pure cultures of a slow-growing fongus. The first sigus of growth hecame visible in about two weeks. In previous attempts to isolate an organism the outer epidermis had always been removed and the underlying discolored tissue cultured on solid merlia. It is quite probable that the failure to isolate the fungus in former attempts mav be attributed to the faet that, because of the slow-growing nature of this organism, the agar plates were discarded as sterile before the fungus became established. It is also probable that by removing the onter epidermis the fungus, which in many cases does not penetrate much beyond the cuticle and soon dies out, may have been entirely removerl. In these isolation attempts the very smallest papnles were always selected nnder the supposition that they were of most recent origin. Later and more eareful observations, however, showed that the small size of most of these minute papules is the result of the failmre of the fungus to persist in the tissues.

Transfers of the fungus were made from the dextrose broth to various solid media, ineluding standard beef, oat meal, and malt-extraet agar. Of several media tested, those best snited for growth and sporulation are oat meal and malt-extract agar.

Artificial Inoculations. Inoculation experiments to determine the pathogenieity of this fungus were conducted in the greenhouse during the following winter. Potted Astrachan trees two years from graft were eut baek to stubs 8 to 10 inehes in length. The new growth which was foreed out was inoeulated with a spore suspension by means of an atomizer. The trees were then plaeed in a moist ehamber at a temperature between 65 and $70^{\circ} \mathrm{F}$. for 36 hours. To insure a constant film of moisture on the stems a eotton wiek, supplying water from an Erlenmeyer flask elevated above the tree, was attaehed at the tips of the young shoots. The first signs of infeetion could be deteeted with the aid of a hand lens twelve days after inoeulation. The eharaeteristic papules formed in about three weeks and from these the fungus was readily reisolated (Pl. I, Figs. 6 and 7 ).

\section{TAXONOMIC CONSIDERATIONS}

The disease is eaused by a dematiaeeous fungus which, from its taxonomie characters, fits most elosely into the genus Helminthosporium, although it has some resemblanee to the genus Napicladium in that some of the spores are decidedly tapering.

The genus Helminthosporium was established by Link (14) in 1809, the type speeies being $H$. velutinum, deseribed as oeeurring on dead deciduous wood.

Von Thuemen (19) in 1875 founded the genus Napicladium to include the forms of Helminthosporium with tapering spores. The validity of this genus, however, was vigorously attaeked by Winter 
(20) shortly after its establishment. Although later recognized in the work of Saccardo and by others, there seems to be, little ground to justify its existence since Von Thuemen's type species $N$. soraueri has been shown to be Fusicladium dendriticum.

Students of mycology and plant pathology often think of the genus Helminthosporium in terms of the graminicolous species only, since these have been recognized as of economic importance for many years, and are among the fungi most easily isolated and cultured. The spores in this group. while exhibiting a certain degree of variability in size, shape, and color, are essentially cylindrical or slightly tapering and the apex more or less bluntly rounded. The great number of saprophytic species occurring mostly on dead wood, many of them inadequately described, however, remain buried in obscurity. In this group a greater variation exists in the size, shape, and septation of the spores, some of them having decided tendencies toward rostrate elongations. On artificial culture media some of these species grow very slowly, especially when compared with the rather rapidly growing graminicolous types.

The fungus causing the disease under discussion, when compared with the graminicolous species, might indeed appear somewhat aberrant. However, when compared with some of the saprophytic lignicolous types its placement in the genus Helminthosporium seems justified. Since the fungus under discussion does not appear to have been described previously, the name $H$. papulosum is suggested.

\section{HELMINTHOSPORIUM PAPULOSUM n. $s p$.}

Conidiophoris surgentibus abundantissime e superficie media corticis prius a fungo interfecti; singillatim aut conjunctis ad basim in fasciculos: $4.2-5.9$ micris diam.; $64-110$ micris in longitudine; typicis 3-multis septatis; fuscis et crassis mœnibus circumdatis; semina solum apice parentibus.

Conidiis paritis substrato naturale; sub-hyalinis vel fuligenosis; 29-45 micris $x$ 6.6-8.2 micris; 3-pluribus septatis, plerumque 3 ; latissimis fere segmento secundo; ad finem basis retusis cum pulla cicatrice et annulare; condicionibus humidis gignentibus angustas, tenues extensiones 3-pluriwm cellarum fragilium qua apicem spori retusum et sine muro circumcurrente relinquunt. Germinatione generatione duorum canalium seminorum poli; germinatione ad basim observato solum per hilum.

HABITAT: In cortice Pyri mali et Pyri communis. Collecto prope Urbem Raymonidiam in Virginia Occidentali, mense Septembri A. D. $M C M X X X$.

Conidiophores arising most abundantly from the central surface of the scaly bark plate previously killed by the fungus; singly or united at the base into fascicles; measuring 4.2 to 5.9 microns in diameter; 64 to 110 microns in length; typically 3 to many septate; dark-brown and thick-walled; producing spores at the tip only.

Conidia produced on the natural substratum; sub-hyaline to fuli- 
genous; measuring 29 to 45 microns by 6.6 to 8.2 microns; 3 to more septate, usually 3 ; widest usually at the second segment ; basal end blunt with pronounced clarkened amular scar; under moist conditions tending to produce narrow, thin-walled rostrate elongations of :3 to more cells which are easily broken off, leaving the apex of the spore blunt and without a peripheral wall. Germination by prorluction of two polar germ tubes; basal germination observed through the hilum only.

Hasita't : Occurring on the bark of Pyrus malus and Pyrus communis, on which it causes a disease described herein as "black pox", which in some instances has proved very destructive. Manifested by producing elevations of the smooth bark in the form of blackish papules, later developing into a pitted or scaly bark condition. Collected near Raymond City, West Virginia, in September, 1930.

Cultural Characteristics. On artificial culture media on an agar plate the fungus grows very slowly and under most favorable conditions produces in 30 days a colony about an inch in diameter (Pl. III, Fig. C). The optimum temperature for growth and sporulation is ahnut $28^{\circ} \mathrm{C}$., no growth below $15^{\circ} \mathrm{C}$. In test-tube cultures the growth is black and almost entirely submerged. forming densely-matted masses of chlamydospores in the medium. The best growth and sporulation is obtained on media rich in organic food materials such as are provided in oatmeal and malt extract. Conidiophores arise either as terminal or as lateral branches from the hypha. When forming laterally they often arise from a chlamydospore. The conidia produced on artificia! media are much more irregular in size and shape than those produced on the natural substratum. A rather abrupt narrowing often oceurs at the third or fourth segment, with the subsequent segments of uniform width giving the spore a bowling-pin or bottle-shaped appearance. Degenerative tendencies are also in evidence, especially tendencies toward eatenulation, with the conidia sometimes interspersed with sporophoric processes. Similar degenerative tendencies have been recorded by Drechsler (10) in some of the graminicolous species.

A rather unusual characteristic of the conidia produced on artificial media is the presence of spherical vesicles surrounding the peripheral wall of certain spore segments. These vesicles are produced, usually after the third or fourth segment is formed, by an exudation through the apex. The subsequent segments produced protrude through this exudation which is retained on the mature conidium as an enveloping sheath (Pl. III, Fig. B ; also Pl. VII, Fig. C).

\section{"BLACK POX" (Helminthosporium papulosum)}

This disease, although formerly identified as measles, has been shown to be of a different nature. The name "black pox" is, therefore, suggested, since this name adequately describes the disease and does not conflict with the terminology now in vogue for any similar bark disease. the disease in its early stages is characterized by the formation of welldefined elevations of the epidermis in the form of papules, which appear 
soon after infection has taken place, due to the formation of a phellogen initiated in the cortical cells in response to the stimulation of the invading organism (Pl. Y, Fig. A). In many instances the fungus dies out and no further development takes place until the papules slough off in the normal course of bark exfoliation. In other cases, however, secondary enlargement takes place around the base of the original papules which sometimes form circular, dark-colored, sunken areas 6 to $12 \mathrm{~mm}$. in diameter, with the original papules projecting in the center ( $\mathrm{Pl}$. I). In such cases the fungus breaks through the original periderm which was laid down in the cortex; a new phellogen is initiated and the process is repeated until the necrotic tissue extends deep into the pericycle and in some instances even to the cambium. After the fungus has run its comse and the process of healing begins, the dead tissue cracks about the periphery of the spot. This tissue occasionally excorticates, leaving a pit in the bark which soon heals over. In most cases, however, the dead tissue adheres and in such spots the fungus continues to live saprophytically and to sporulate perennially. The fungus infects directly through the cuticle; infections through lenticels have never been observed.

The disease as it occurs on bark of different ages presents a varied picture. On the watersprouts and twigs of the season's growth the new infection usually makes its first appearance in August in the form or well-defined conical, shining, blackish papules (PI. I, Fig. 6). The secondary enlargement of the lesions around the bases of these papules can often be noted by the end of the first season. This is especially true on Rome Beauty (Pl. I, Fig. 3). Although the number of initial infections per unit area on this variety is always less than on Astrachan, the number and size of the secondary enlargements are much greater and often cause girdling of the twigs, and for this reason Rome often succumbs to the disease more readily than Astrachan. The smooth-barked twigs and branches remain susceptible for several years. In this way the disease becomes cumulative so that the number of papules per unit area is likely to be greater on bark several years old than on bark of the season's growth. Since the bark becomes more resistant with age the papules resulting from later infections are often very minute and produce little or no secondary enlargement. Twigs several years old will, therefore, often present lesions in all stages of development and excortication. On the other limbs and on the main trunk of the tree on certain varieties such as Astrachan and Maiden Blush the bark assumes a fine flaky appearance very similar to the bark scaling that follows severe infestations of San Jose scale, while on Rome the bark becomes pitted (Pl. VI). On some varieties, especially Astrachan, the old bark becomes thick and more or less spongy; the wood becomes brittle and possesses little vitality, thus inviting secondary wood-rot organisms. Trees, although severely infected, may linger for many years, the lower limbs dying first and death gradually progressing upward until only a few live branches remain in the top of the tree (Fig. 1).

The relative resistance of the varieties under observation appeared to be very sharply defined. Astrachan, Maiden Blush, Rome, and 
Grimes were found most susceptible, while Transparent, Pound Royal, Chenango, Summer Queen, York, and Gano, although interspersed among diseased trees, showed no signs of infection. Under experimental conditions Dutchess, Delicious, and Golden Dedicions also became infected.

Fruit Infection. In the summer of $19: 32$ the writer received from the department of botany, Purdue Agricultural Experiment Station, several specimens of Grimes Golden apples infected with small, black, circular, slightly sunken spots (Fig. 3). These apples were collected from trees infeeted with "black pox". Isolations from ten of these spots all yielded pure cultures of Helminthosporium papulosum. Inoculations with this fungus on about three-fourths-grown Rome and Grimes apples yielded similar spots. This phase of the disease does not appear to be important under the conditions prevailing in West Virginia. When it does appear it might readily be mistaken for the fruit spot eaused by Cylindrosporium pomi.

Control Measures. Since the experiments in 1929 gave evidence that the number of new infections could be appreciably decreased by spraying, spraying for control was again undertaken in 1933. However, since no power-spraying equipment was available in the vicinity of the

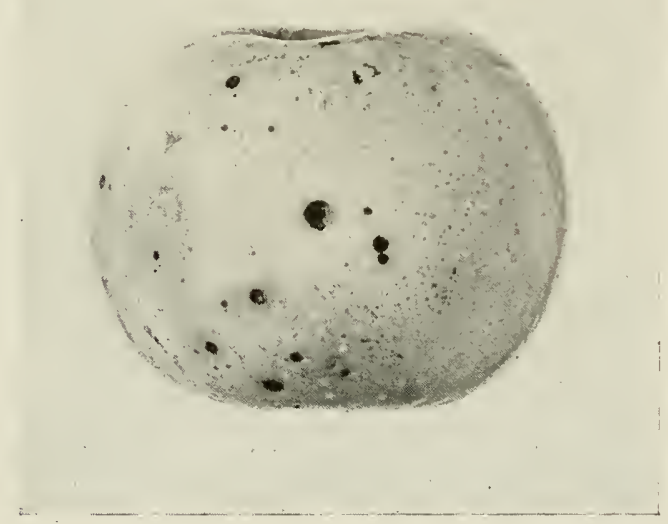

FIG. 3-Grimes apple infected with Black Pox

crchard, it was decided to spray young trees three years from graft with an improved knapsack sprayer which was capable of delivering spray at 150 pounds pressure. Twenty-four three-year Astrachan trees were planted early in the spring. These trees were planted in a circle under the overhanging branches of a 28-year-old Astrachan tree badly diseased. Starting at a point in the circle one tree was sprayed with Bordeaux 4-4-50, the adjacent tree was sprayed with lime sulphur, summer strength, and the third tree was left as a check. This procedure was repeated so that 8 trees received Bordeaux, 8 trees lime sulphur, 
and 8 trees remained as checks. The sprayed trees received an applieation every ten days from the first of May to the first of September. A check of the results was made on September 15 and it was noted that six of the check trees became infected. One had died and one showed no infection. The eight trees receiving Bordeaux spray were all free from the disease. Six of the trees sprayed with lime sulphur were free from infection, while two showed a few spots of infection. It is not to be expected that mature trees can be as thoroughly covered with spray material as was the case in this experiment. However, the evidence is sufficient to point out that in orchards on which the approved methods of spraying are consistently practiced the disease is not likely to become as destructive as was the case in the Kanawha orchard. The removal of highly susceptible varieties when the disease is first noticed in an orchard may also aid in keeping the disease in check.

Distribution. This disease is apparently distributed over a considerable area. The writer has received infected apple twigs from New Jersey, Mississippi, and Indiana, and also on Bartlett pears from Mississippi. He has observed it also in apple orchards in Ohio and West Virginia.

\section{INTERNAL-BARK NECROSIS}

With the advent of the Delicious as an important commercial variety, another type of bark disease generally called measles came to our attention. Since this disease differs significantly from the disease first described by Hewitt and Truax as measles, the name "internalbark necrosis" is tentatively suggested pending the establishment of its true relationship to bark diseases of similar appearance.

In this disease the necrotic tissues, instead of extending from the epidermis inward, appear to have their inception deep in the cortex and pericycle with, at first, apparently healthy tissue above and beneath them. Later groups of such necrotic cells are often completely surrounded by a periderm and become encysted in the bark ( $\mathrm{Pl}$. IV, Fig. B).

The first externally visible manifestations of the disease are elevations of the epidermis due to the hyperplasia which takes place in the cells bordering the necrotic tissue. These elevations are usually larger and present more variation in size and shape than those in the true measles.

In cases of light infection where the pockets of dead tissue in the bark are comparatively small and isolated, the external elevations develop into more or less hemispherical papules. However, in cases where they are larger, irregular in shape, or closely aggregated, the bark becomes unevenly elevated into undulating ridges, the contour of which may gradually change, since the upheaval of the bark often continues for more than one year. The periderm covering the papules or ridged areas may remain smooth and apparently normal throughout the first season, or it may assume a reddish or dark-brown pigmentation. In other cases dead, slightly sunken patches appear on the 
summit of some of the ridged areas with the periderm turning limht brown and beginning to check and scale by the end of the first season.

In the eourse of time the number of such dead areas increases. the radial development of the lark is retarled, and numerous short, irregular cracks appear. The checking of the bark and scaling of the periderm may progress for several years until the bark on severely affected limbs and branches assumes a characteristic scaly, cracked, and roughened appearance (Pl. II, Figs. 6 and 7 ).

On removing a slice of the periderm from a branch or twig rather recently affected, there are disclosed in the cortical region numerous brown, more or less circular, areas of dead cells. These are surrounded by a halo of light-green, water-soaked appearing tissue. Upon cutting deeper into the bark larger and more irregular areas of dead cells are noted. Sometimes narrow black streaks, a centimeter or more in length, of dead pericyclic fibers will be disclosed. Cross sections of such strands will often show them to be completely surrounded by a phellogen (PI. IV, Fig. B).

As far as is known this disease oceurs mostly on Delicious and its sports, although the writer has observed an instance where a similar appearing disease was found on Grimes, Rome, and N. W. Greening. On these varieties the disease was localized on a few branches that were in elose proximity to severely diseased Delicious trees. Several mild cases of the disease were also found on Golden Delicious trees located in an orchard where the disease was extensively present on Delieious.

This disease is often irregularly distributed in the tree and sometimes localized on certain branches. Instances have been observed in which the disease began at the ground line and extended upward in a band one-fourth to one-third of the circumference of the trunk. When it reaches the first scaffold limbs it usually follows along one or several of these limbs, the limbs on the affected side of the trunk usually suffering most severely. Trees in which the limbs on one side are dead while those on the other side are still alive, and perhaps only slightly diseased, are not uncommon. Trees with one-sided infection can be most readily detected in the fall of the year, since defoliation is premature on severely affected branches. In other cases the disease will be found distributed fairly uniformly throughout the entire tree.

From the observations so far made it appears that this disease, in most cases, has its inception rather early in the life of the tree, and that the trees only slightly affected may later outgrow the disease, while those severely affected will sometimes continue to live for many years in a weakened and stunted condition.

No experimental evidence has so far been obtained on the nature of the causal agent of this disease, nor has the writer been successful in transmitting it artificially. It cannot be attributed to unfavorable soil or drainage conditions since it occurs under all conditions of tillage and drainage; on high as well as on low ground; on fertile as well as on poor soil. It is not the result of winter injury, for its development on wood 
of the season's growth has been observed during the months of July to October for several consecutive years.

Numerous attempts have been made to transmit the disease by grafting, using scion wood from diseased trees, and often using actually diseased wood. Several hundred such grafts have been made during a period of five years. Some of these trees have by this time attained a height of five feet, but in no instance has the slightest sign of the transmission of this disease been noted. Attempts to transmit the disease by taking aphids from diseased trees and transferring them to healthy trees have been unsuccessful. Repeated attempts have been made to isolate an organism from the diseased tissues. Although most cultures remain sterile, numerous types of bacteria have been isolated, none of which, however, has so far been found responsible for the disease.

For several consecutive years experiments to study the transmission of this disease were conducted near Paw Paw, West Virginia, in which small Delicious trees were planted around badly-infected 18year-old Delicious trees, but in no instance was the disease transmitted to the young trees. In 1933 the experiment was shifted to an orchard near New Cumberland, West Virginia, where the disease was making heavy inroads in young Delicious orchards about six years from planting. Four young Delicious whips, two year's from graft, were planted nuder the limb spread of each of three 8-year-old, badly-affected trees. One eight-year-old, very badly affected tree was enclosed in an insectand moisture-proof shelter which admitted air and light. A six-year-old healthy Delicious tree from the experimental garden at Morgantown was carefully dug, transported to this olchard, and planted in a spot where an infected tree had died from the disease the previous season.

Frequent.visits were made to this orchard during the growing season. Slight evidence of infection was noticed on July 10 on the new growth on some of the trees that had been affected for several years. In most cases infection on the season's growth appeared first on branches that were severely affected the previous season. The observations during the last three years have indicated that the most pronounced symptoms on the new growth appear during late summer. No infection was apparent on the young trees planted around affected trees until the first of September, and by the 9 th of October these trees were so badly affected that three of them were dying. Examination of these trees disclosed that the bark showed the characteristic external elevations and ridges, and upon slicing the bark the brown pockets of dead cells came into evidence. The infection did not stop at the ground line but extended to the junction of the graft and no further.

The six-year-old tree planted in the place where a tree had died the previous season as a result of this malady became so badly infected that some of the branches were dying. Here the infection also extended to the junction of the graft, which was about six inches below the ground line. Examination of the root system showed that it had made normal growth and otherwise was in sound condition.

The diseased tree enclosed in the shelter, excluding insects and moisture, showed no signs of infection on the new growth. 
Distribution and. Irarietal susceptibility. 'This disease is apparently' distributed throughout the entire United States wherever the variety Delicious is being grown, and although the Idicious and its sports are by far the most susceptible varieties, the disease has, in rare cases, been noted on Grimes, Nortluwestern Greening, Rome, Jonathan, and King David. The writer recently noted a similar appearing disedse on $M a-$ lus coronaria.

\section{MEASLES}

A third type of papular apple-bark disease has also been observed, but since this form apparently is of little importance in West Tirginia little attention has been given to its study thus far. This disease corresponds in all respects to the "measles" originally described by Hewitt and Truax. In this type the papules are much smaller than those in the two forms of bark disease previously described in this bulletin. They may occur more or less isolated but more often in closely aggregated groups (Pl. T, Fig. B). Patches of such aggregated papules are often suffused with a reddish tinge and it is this phenomenon that prompted the term measles. This disease is found mostly on unthrifty trees or old trees that are beginning to decline. The affection is nearly always confined to bark several rears old. In this state it is found most commonly on Jonathan, but here also unthriftiness is ascribed as the predisposing factor.

\section{SLTIMARY AND DISCUSSION}

This investigation deals with a number of papular apple-bark diseases which have previously been identified as measles under the supposition that they are identical with a disease described by Hewitt and Truax under that name. Rose later reported what appears to be the same disease under the name "pimple canker". In a later publication, however, Rose described and attempted to associate a bark disease with a blister spot on apple. Rose believed this disease to be a form of "measles" but from his descriptions and illustrations it appear's to be a different disease. Rose isolated a number of bacterial organisms from the diseased bark and produced a blistering in artificial inoculations with one of these organisms which he designated as Psendomonas papulans. The descriptions of his inoculation experiments, however, are very meager. Rhoads, who later worked at the same laboratory and in the same orchards, could not associate Ps. papulans as the causative agent of "measles".

Later workers in this country and abroad have reported papular and bark-blistering diseases from which an organism similar to $P s$. papulans has been isolated and which upon artificial inoculation will produce a bark-blistering only when the epidermis is ruptured. In most cases, however, their experiments and conclusions lack the air of finality.

There apparently exists at present considerable confusion as to the cause and identity of these bark diseases and their relationship to "measles". Such a confusion can easily arise, since the etiology of most of these diseases has never been definitely established and since these diseases present several stages as a result of development and also as a result of varietal response. 
The writer has shown that there are several distinct diseases which previously have been called "measles" and has attempted to classify them. A parasitic fungus, Helminthosporium papulosum, has been shown to be the cause of one of these diseases, and the name black pox has been suggested because of the shiny, blackish papules which are characteristic of the early stages of this disease especially when occurring on the watersprouts and twigs of the season's growth. This disease can be controlled to a considerable extent by thorough spraying either with Bordeaux or lime sulphur.

Another destructive and widespread type of bark disease on the variety Delicious, which is also commonly known as "measles", has been extensively studier and has been shown to bear no relationship to the black pox disease. In this disease, groups of necrotic cells often appear deep in the bark. This disease often attacks young trees in vigorous growing condition. Trees severely affected may soon die; others continue to linger for several years in a weakened and stunted condition, while trees only slightly affected usually recover. The cause of this disease has not been established. This disease will be tentatively designated as internal-bark necrosis pending the establishment of its relationship to the third type or true measles, which has also been observed in West Virginia, mostly on the varieties Jonathan and York, but which has not been extensively studied because it does not appear to be very injurious to the tree. It appears mostly on older trees that have passed their prime or on trees that are unthrifty apparently from some other cause.

\section{IITERATURE CITED}

(1) Adums, J. F.

(2) Axonymous.

(3)

(4)

(5)

(6)

(7) Berg, Axtioxy.
NOTES ON PLANT DISEASES IN PENNSYLVANIA FOR 1916.

Rept. Pennsylvania State College, 1916-1917: 329-336; fig. 2-4. 1919.

APPLE MEASLES.

30th Ann. Rept. New Mex. Agr. Exp. Sta. 19181919: 18.

APPLE MEASLES. 36th Ann. Rept. New Mex. Agr. Exp. Sta. 1924-1925: 18.

APl'LE MEASLES. 37th Ann. Rept. New Mex. Agr. Exp. Sta. 1925-1926: 17 .

APPLE MEASLES. 38th Ann. Rept. New Mex. Agr. Exp. Sta. 1926-1927: 20.

APPIE MEASLES.

39th Ann. Rept. New Mex. Agr. Exp. Sta. 1927-1928: 18.

A PAl'LLAR TYPE OF APPLE MEASLES.

Science n.s. $\tau_{\ell}^{\prime}: 485-486.1931$. 
(8)

(9)

(10) Drechsler, Ciiss.

(11) HewitT, J. L., AND H. E. Truax.

(12) Hopkixs, C. J.
APULE MEASIES.

(Abstract) Phytopath. 2::4. 1932.

A FRUT SPO'T ASSOCLATEW WITH THE PAPTLAR TYPE OF" APPLE WHASLES.

(Abstract) Phytopath. \&3:4. 1933.

SOME GRAMNICOLOCS SPECIES OF HELMINTHOSPORIUN.

Jour. Agr. Res. 24: 641-739; pl. 33.1923.

AN FNKNOWN APPLE UISEASL.

Ark. Agr. Exp. Sta. Bull. 112: 481-491; figs. 14. 1912.

AN APPLE DISEASE OCCCRRING IN THE ELGIN DISTTICT.

Union South Africa Dept. of Agr. Sci. Bull. 61: 1-17; pl. I (fig. 4). 1927.

(13) LaCY, MARgaret S., AND WaLter J. Dowson

A PACTERIAL CANKER OF APPLE TREES.

Ann. Appl. Biol. 18: 30-36; pl. 1 (fig. 3). 1931.

(14) LINK, J. H. F.

Ges. Nat. Freunde Berlin Mag. 3:10. 1809.

(15) Rhonds, Artilur S.

APPLE MEASLES WITH SPECIAL REFERENCE TO THE COMPARATIVE SUSCEPTIBILITY AND RESISTANCE OF APILE VARIETIES TO THIS DISEASE IN MISSOURI.

Phytopath. 14: 289-314; pl. 5 (fig. 1). 1924.

(16) RoBerts, J. W.

APPLE TARGET CANKER, MEASIES, AND ROUGH BARK.

(Abstract) Phytopath. 2/:16. 1934.

(17) Rose, D. H.

REPORT OF THE PATHOLOGIST.

Missouri State Fruit Exp. Sta. Rept. 19131914 (Bull. 24) : 30. 1914.

BLISTER SPOT OF APPLES AND ITS RELATION TO A DISEASE OF THE APPLE BARK.

Phytopath. 7: 198-208. 1917.

(19) vox Thuemex, F.

NAICLADILM, EINE NEUE HYPHOMYCETESGATTUNG.

Hedwigia 14: 3-4. 1875.

(20) Winter, Georg.
UERER NAPICLADIUM SORACERI THUEMEN. Hedwigia 1\%: 35-36. 1875. 


\section{EXPLANATION OF PLATES}

\section{PLATE I (BLACK POX)*}

1-3 Black pox on Rome Beauty, showing secondary enlargements around original papules

4-5 Black pox on Astrachan

6-7 Black pox papules on Astrachan four months old from artificial inoculations

\section{PLATE II (INTERNAL-BARK NECROSIS)*}

1-2 One-year-old Delicious twigs affected with internal-bark necrosis, showing papules and bark ridging

3-4 Delicious twigs with slice of outer bark removed, showing dark streaks (3) and pockets of necrotic tissues (4)

5,6,7 Delicious twigs showing progressive stages in the development of rough bark

\section{PLATE III (BLACK POX)}

A. Photomicrograph of spores of Helminthosporium papulosum produced on natural substratum; $\mathrm{x} 850$

B. Photomicrograph of spore of Helminthosporium papulosum from oatmeal agar, showing development of spherical vescicles; $x \mathbf{7 5 0}$

C. Growth of the fungus on malt extract agar 30 days after inoculation at $15,18,28,30$, and 34 degrees Centigrade.

\section{PLATE IV (INTERNAL-BARK NECROSIS)}

A. Longitudinal section of one-year-old Delicious bark, showing inclusions of necrotic tissues; $x 76$

B. Transverse section showing strands of encysted dead fibers; $x 76$

\section{PLATE V (BLACK POX)}

A. Longitudinal section of papule of Black Pox; $\mathrm{x} 56$

B. Types of measles. Upper twig showing small, densely-crowded papules on York Imperial. Middle twig showing larger and more or less isolated papules on Jonathan. Lower twig showing closely-aggregated papules on Jonathan, forming scurfy bark

\section{PLATE VI (BLACK POX)}

Scaly and pitted bark on older limbs (slightly reduced)

\section{PLATE VII $\dagger$ (BLACK POX)}

A. Spore types of Helminthosporium papulosum from natural substratum; x 700

B. Germinating spores; $\mathrm{x} 700$

C. Spore types of Helminthosporium papulosum developed on malt extract agar, showing catenulation and spherical vesicles; $x 700$

D. Conidiophores from natural substratum; $\mathrm{x} 700$

* Slightly reduced.

$\dagger$ These drawings were made with the aid of a Leitz projecting apparatus by Miss Genevieve B. Clulo. 
PLATE I (BLACK POX)
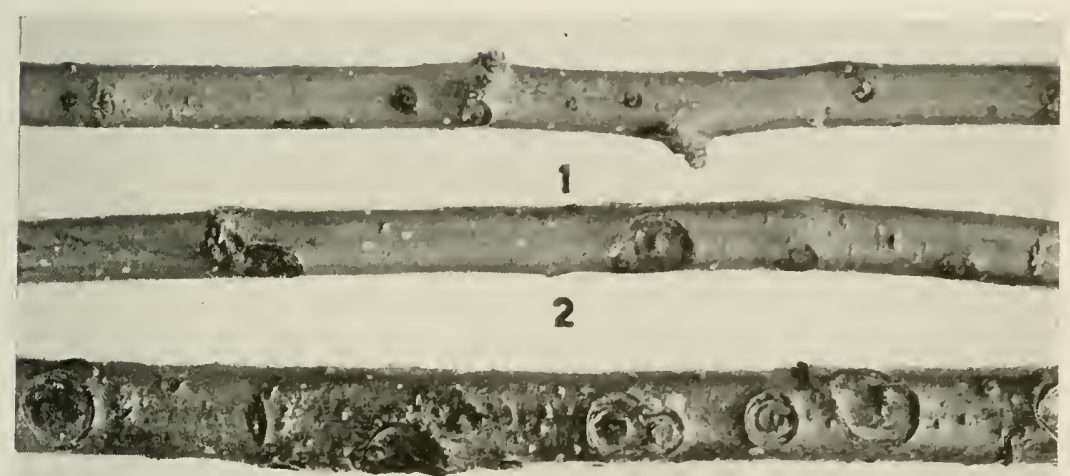

3

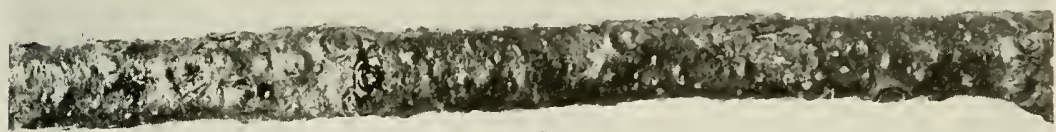
4
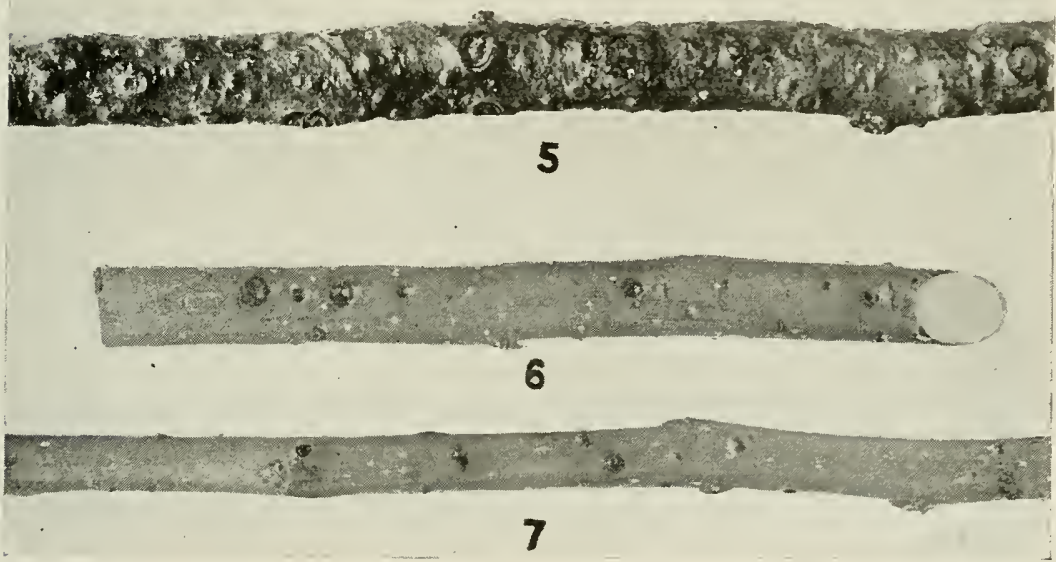
PLATE II (INTERNAL-BARK NECROSIS)

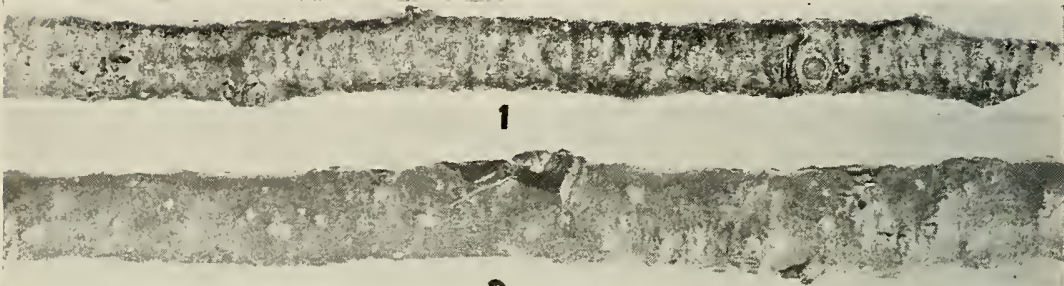

2

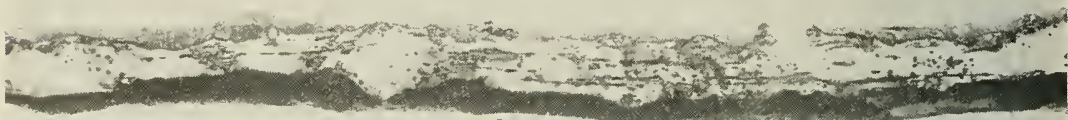

3

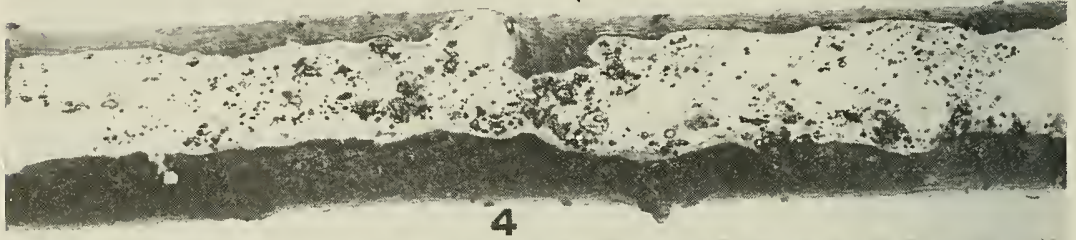

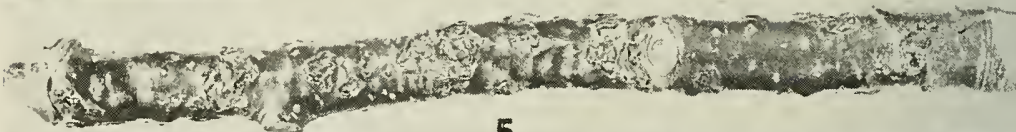

5

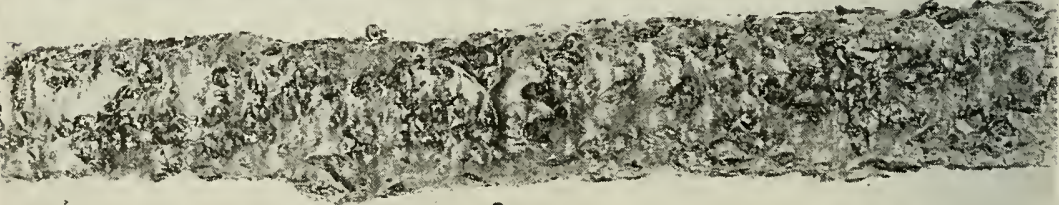

6

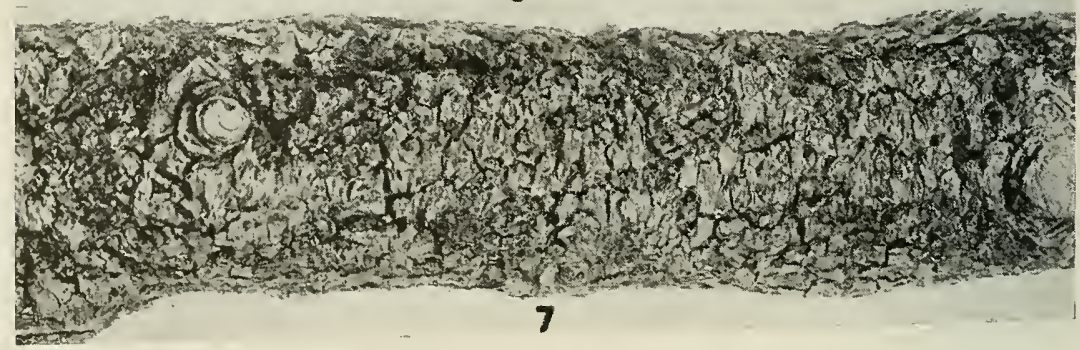


PLATE III (BLACK POX)
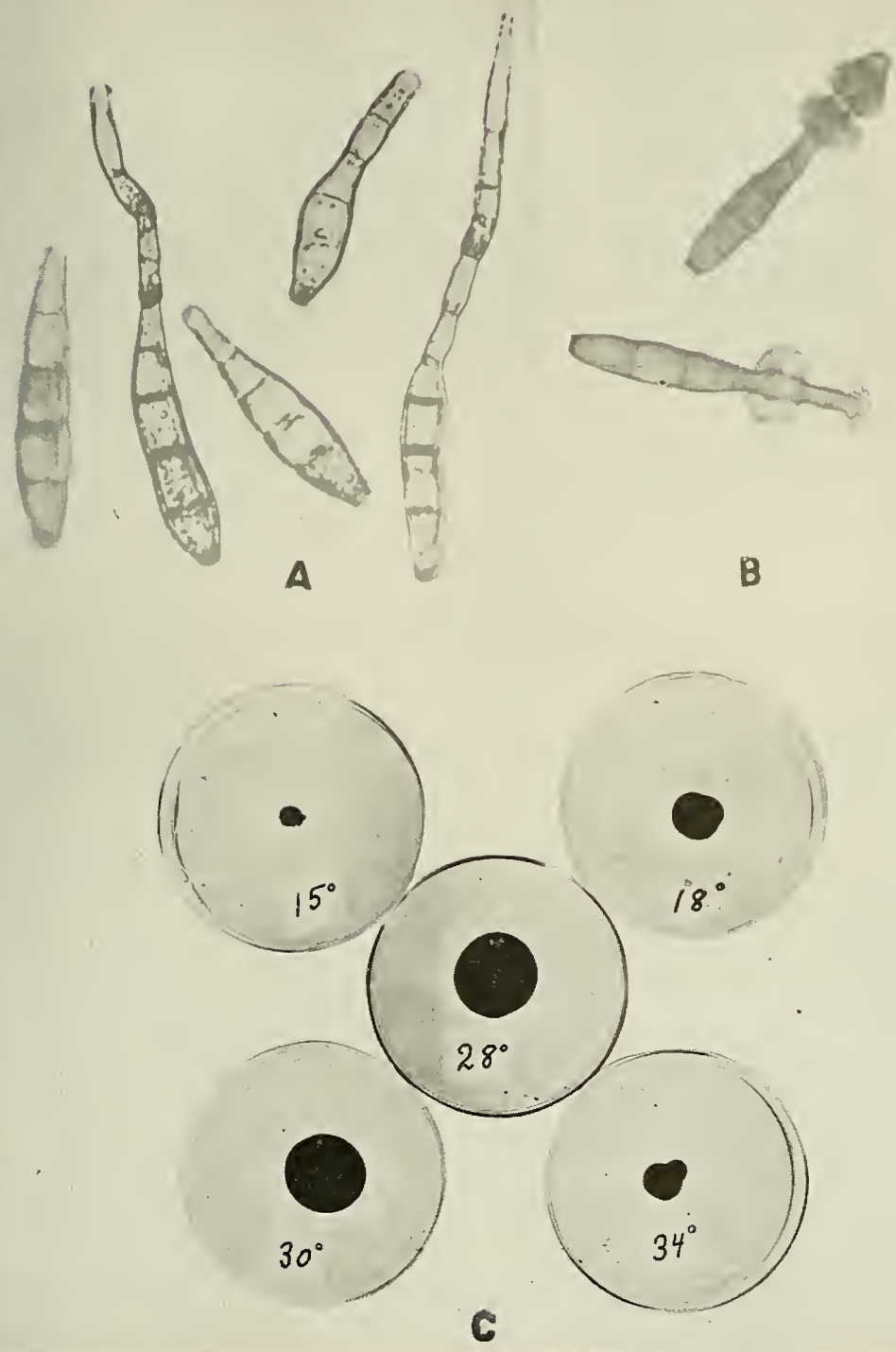


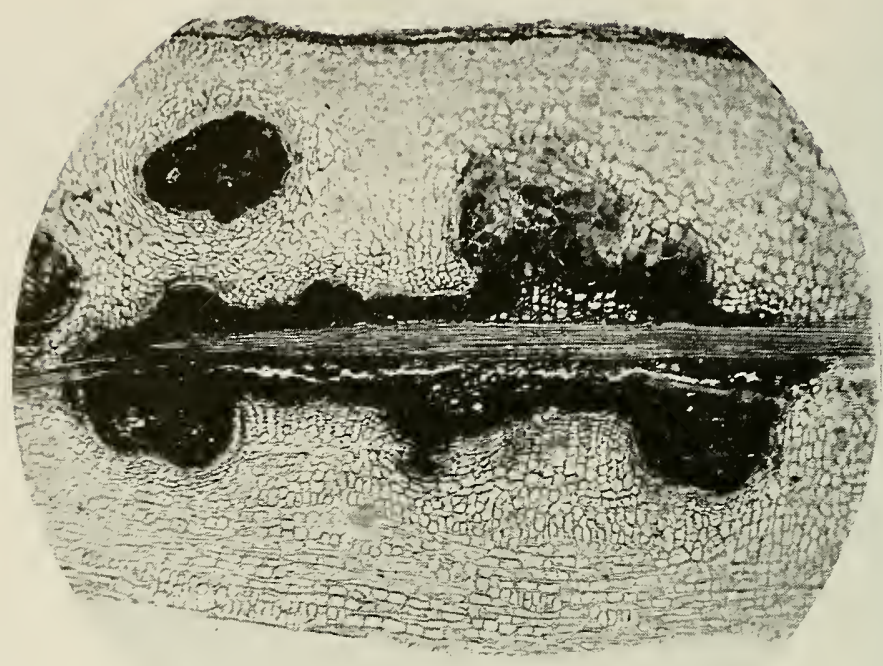

$\mathbf{A}$

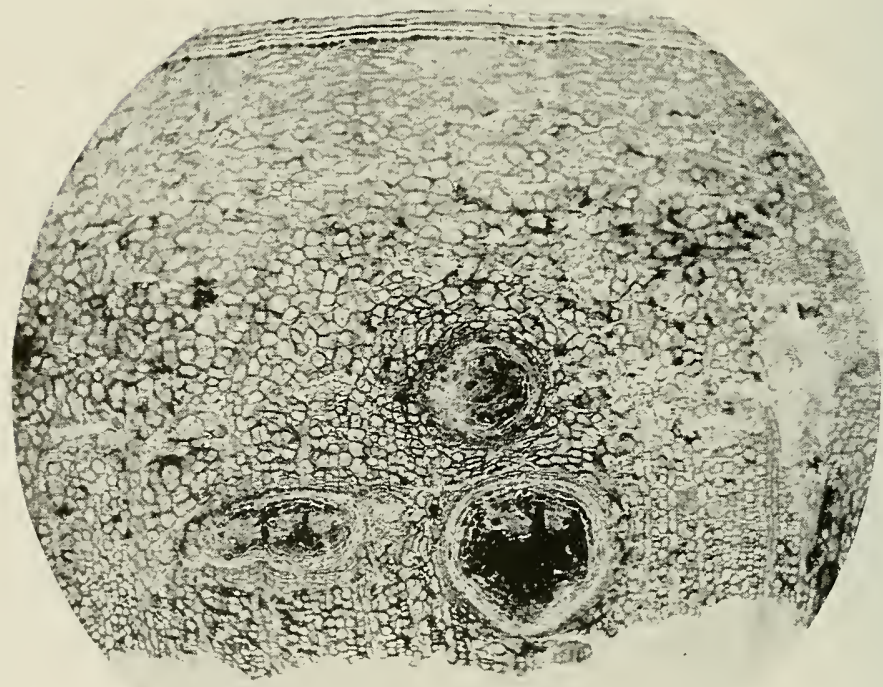

B 

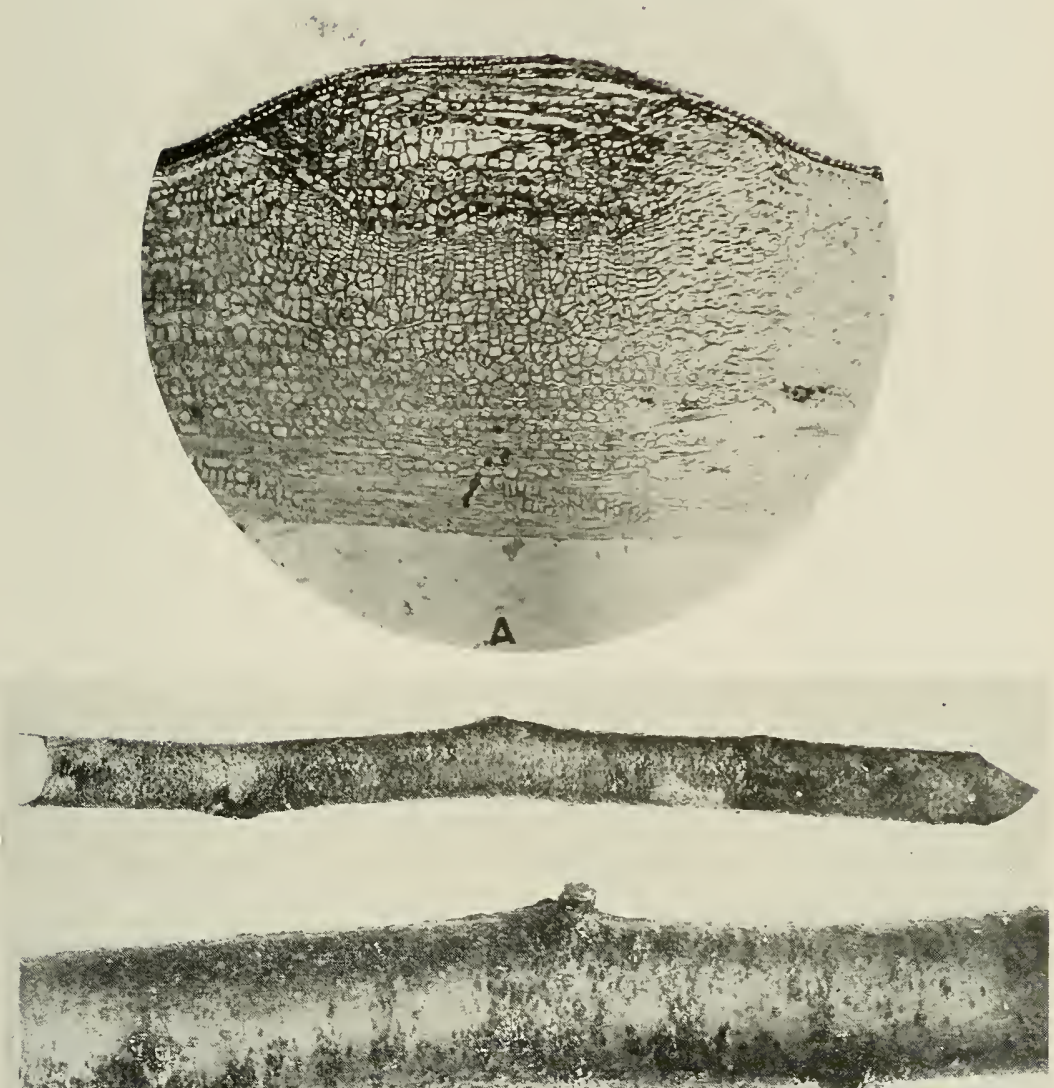

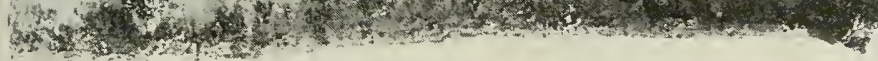
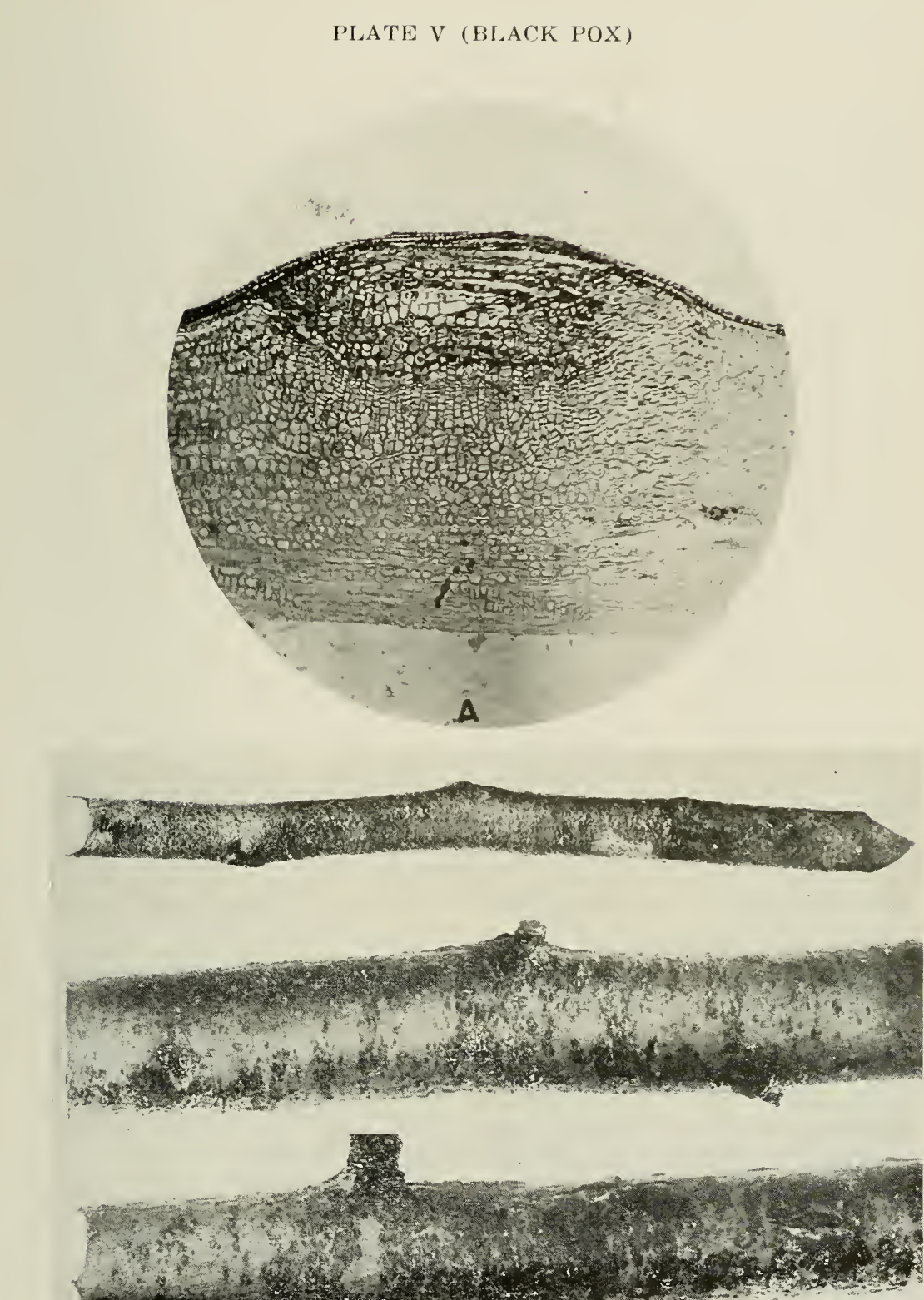

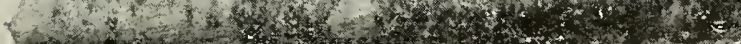

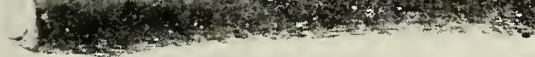

$-\mathbf{B}$ 
PLATE VI (BLACK POX)
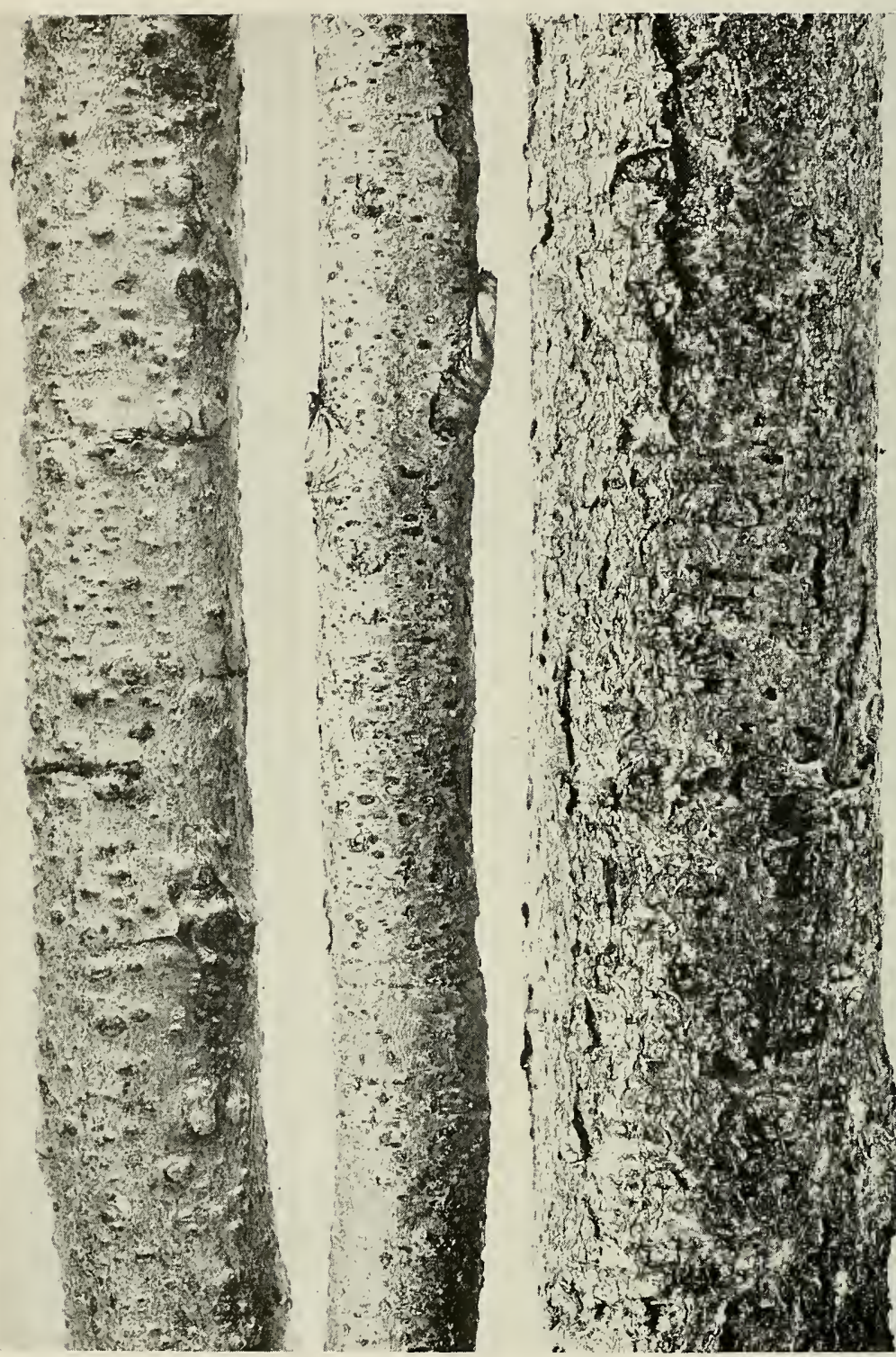

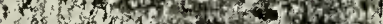

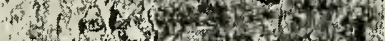

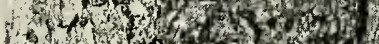

I

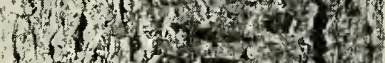

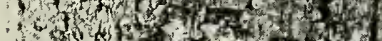

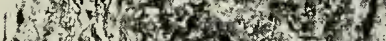

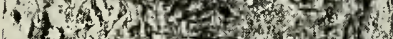

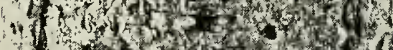

(5) 1 ,

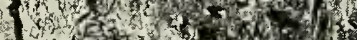

(1)

Wh.

N 1 ro

1 Thillow

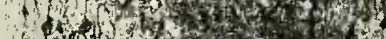

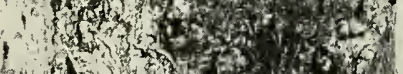

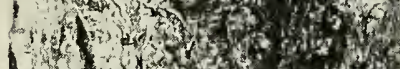

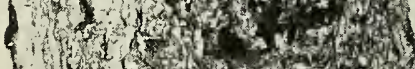

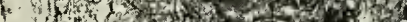

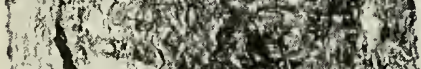

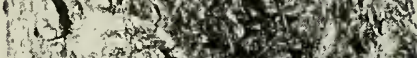

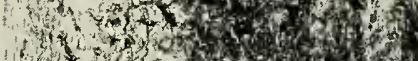

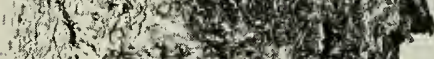

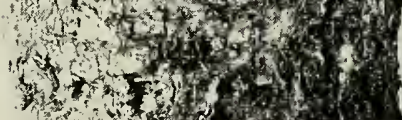

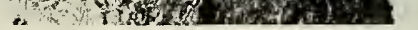


PI,ATE VII (BIACK POX)
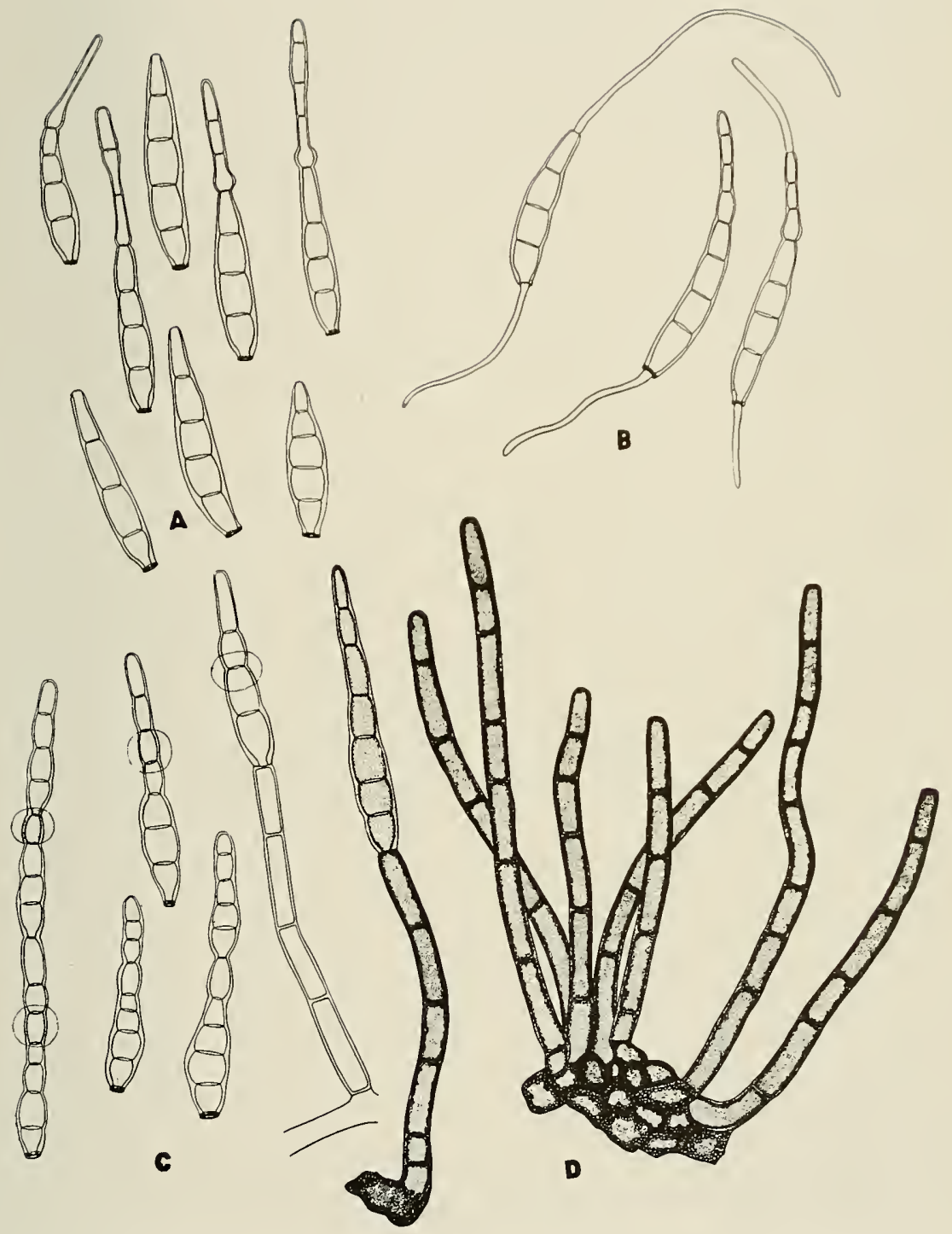
